\title{
Virulence Characteristic of Avian Pathogenic Escherichia coli (APEC) Isolates
}

\author{
Karakteristik Virulensi Isolat Avian Pathogenic Escherichia coli (APEC) \\ Sruti Listra Adrenalin ${ }^{1}$, Lynda Nugrahaning Imanjati ${ }^{2}$, Ima Fauziah ${ }^{2}$, Vinsa Cantya Prakasita ${ }^{3}$, Sitarina Widyarini ${ }^{4}$, \\ Agnesia Endang Trihastuti Wahyuni5* \\ ${ }^{1}$ Department of Microbiology and Imunology, Faculty of Veterinary Medicine, Brawijaya University, \\ Malang 65151, Indonesia \\ ${ }^{2}$ Faculty of Veterinary Medicine, Universitas Gadjah Mada, Yogyakarta 55281, Indonesia \\ ${ }^{3}$ Department Biology, Faculty of Biotechnology, Duta Wacana Christian University, Yogyakarta \\ ${ }^{4}$ Department of Pathology, Faculty of Veterinary Medicine, Universitas Gadjah Mada, \\ Yogyakarta 55281, Indonesia. \\ ${ }^{5}$ Department of Microbiology Faculty of Veterinary Medicine, Universitas Gadjah Mada, \\ Yogyakarta 55281, Indonesia \\ *Email:wahyuni_aeth@yahoo.com
}

Naskah diterima: 10 Juni 2019, direvisi: 2 januari 2020, disetujui: 30 Maret 2020

\begin{abstract}
Abstrak
Avian pathogenic Escherichia coli (APEC) merupakan penyebab kolibasilosis pada unggas, salah satu penyakit pernapasan yang menyebabkan permasalahan yang serius di industri perunggasan. APEC dapat mengakibatkan tingginya jumlah kematian dan angka afkir, penurunan produksi, dan tingginya biaya pengobatan. Manifestasi kolibasilosis yang biasa terjadi adalah airsacculitis, perihepatitis, dan perikarditis. Serotipe APEC yang banyak diidentifikasi di lapangan adalah O1K1, O2K1, dan O78K80. Embryo lethality assay (ELA) adalah salah satu metode yang dapat digunakan untuk mengetahui virulensi serotipe APEC. Tujuan dari penelitian ini adalah untuk mengetahui karakteristik virulensi isolat APEC berbagai serotipe. Lima isolat APEC serotipe O1K1, $\mathrm{O} 2 \mathrm{~K} 1, \mathrm{O} 78 \mathrm{~K} 80, \mathrm{O} 157 \mathrm{H} 7$, dan unknown serotype digunakan untuk pengujian virulensi dengan menginokulasikan bakteri ke dalam cairan alantois telur ayam berembrio spesific pathogenic free (TAB SPF) umur 12 hari. Masingmasing serotipe dibutuhkan telur sebanyak 10_butir, dengan dosis bakteri 100-500 CFU/ $0.1 \mathrm{ml}$. Candling dilakukan setiap hari, sampai umur embrio 18 hari, untuk menentukan jumlah kematian dan perubahan lesi patologi. Setelah diamati selama 6 hari, persentase TAB yang mati setelah diinokulasi dengan APEC serotipe O1K1, O2K1, unknown serotype adalah 100\% (10/10), serotipe O78K80 90\% (9/10), dan serotipe O157H7 70\% (70\%). Seluruh ayam yang mati mengalami lesi patologi adanya hemoragi daerah kranial dan ektremitas. Seluruh isolat $E$. coli dalam penelitian ini memiliki virulensi tinggi.
\end{abstract}

Kata Kunci: avian pathogenic E. coli (APEC); serotipe E. coli; virulensi; embryo lethality assay

\begin{abstract}
Avian pathogenic Escherichia coli (APEC) is a cause of colibacillosis in poultry, one of the respiratory disease that causes serious problems in the poultry industry. The APEC can cause high mortality and culling, decreased production, and high costs of treatment. Manifestations of colibacillosis are airsacculitis, perihepatitis, and pericarditis. The APEC serotypes that are widely identified in the field are O1K1, O2K1, and O78K80. Embryo lethality assay (ELA) is a method for to determine the virulence of APEC serotypes. The aim of this study is to determine the virulence characteristic of APEC isolates. Five APEC serotypes O1K1, O2K1, O78K80, $\mathrm{O} 157 \mathrm{H} 7$, and unknown serotype were used for ELA method by inoculated E. coli into chorioallantoic of specific
\end{abstract}


pathogen free 12-days old embryos. Each group of 10 embryos, inoculated E. coli dose of 100-500 CFU/ $0.1 \mathrm{ml}$. Candling was carried out for 6 days (18-days old embryo) to determined the mortality and pathological lesions. The percentage of embryo mortality post-inoculated with APEC O1K1, O2K1, unknown serotypes were $100 \%$ (10/10), O78K80 serotype was 90\% (9/10), and O157H7 serotype was 70\% (70\%). Lesions of all embryos were cranial and extremity hemorrhage. In this study, E. coli isolates had high virulence.

Key words: avian pathogenic E. coli (APEC); E. coli serotypes; virulence; embryo lethality assay

\section{Introduction}

Respiratory infection is one of the main problems in the poultry industry. The infection causes economic loss due to the increase of mortality and culling, decrease of carcass quality, production, and high costs of treatment. Colibacillosis is one of the respiratory infections caused by APEC. The APEC is the extraintestinal group of $E$. coli which causes various internal organ lesions/ septicemia such as airsacculitis, perihepatitis, pericarditis, cellulitis, egg peritonitis, salpingitis, coligranuloma, omphalitis, and osteomyelitis/ arthritis (Chansiripornchai et al., 2011; Ghunaim et al., 2014; Gross, 1991; Kemmett et al., 2013; Roseliza et al., 2016). This systemic infection occurs when a large number of pathogenic E. coli into blood vessels through the respiratory or digestive tract (Chansiripornchai, 2009).

Prevention of APEC infections has been carried out by vaccination of other respiratory agents and E. coli itself, reducing stress in chickens, predisposition factors, and treatment with antibiotics (Chansiripornchai, 2009; Cortes et al., 2010; Ghunaim et al., 2014; Wibowo and Amanu, 2009). The increase of antibiotics resistance to $E$. coli and residues in meat should be the concern (Gregersen et al., 2010). Whereas $E$. coli vaccination provides a better result if the vaccine serotypes are homolog with field strain (Ahmed et al., 2015; Dho-Moulin and Fairbrother, 1999; La Ragione et al., 2013). In addition, there is no diagnostic tool to differentiate the E. coli isolates from primary (highly virulent), secondary (moderately secondary), or non-pathogenic (avirulent) isolates (Wooley et al., 2000; Oh et al., 2012).

Effective and reliable methods for bacterial virulence testing require a research tool (Andersson et al., 2015). Embryo lethality assay (ELA) can be used to differentiate between virulent and avirulent $E$. coli isolates (Nolan et al., 1992). The ELA method is a sensitive method to determine E. coli virulence in diagnostic laboratories, by the percentage of embryo mortality after inoculation (Oh et al., 2012).

\section{Materials and Methods}

\section{Escherichia coli Isolates}

The E. coli serotypes for inoculated were O1K1, O2K1, O78K80, O157H7, and unknown serotype (collection of Veterinary Medicine Faculty of Gadjah Mada University). All serotypes were reisolated on media eosin methylene blue (EMB), Gram staining, and biochemical tests (Triple Sugar Iron Agar/ TSIA, urea, semisolid, indole, methyl red (MR), Voges-Proskauer (VP), catalase, citrate, sorbitol, glucose, lactose, sucrose, and mannitol). The bacteria were confirmed as $E$. coli then used as an inoculum.

\section{Inoculum}

The inoculum was an isolate that confirmed as E. coli on EMB media, Gram staining, and biochemical tests. The $E$. coli then grown on brain heart infusion (BHI) media at $37^{\circ} \mathrm{C}$ for 24 hours, then washed with PBS solution, and compared with standard McFarland 0.5. The number of bacteria inoculated is $100-500 \mathrm{CFU} / 0.1 \mathrm{ml}$ (Nolan et al., 1992; Powell \& Finkelstein, 1966; Wooley et al., 2000). The determination of the bacteria number was by the total plate count (TPC) method on nutrient agar (NA), with sample dilutions had been standardized with McFarland 0.5.

\section{Embryo Lethality Assay (ELA)}

Fifty-five of specific pathogen free 12-days old embryos were divided into 5 groups based on $E$. coli serotypes (O1K1, O2K1, O78K80, O157H7, and unknown serotype). Each group of 10 embryos treatment and an embryo control was inoculated 
with PBS. Each treatment group was inoculated with each $E$. coli serotype in chorioallantoic. Candling is carried out for 6 days (18-days old embryo) to determined the mortality. Mortality was recorded and observed for pathological lesions (Gibbs et al., 2003; Nolan et al., 1992; Oh et al., 2012; Powell \& Finkelstein, 1966; Wooley et al., 2000). There were virulent characteristic as described by previous study (Wooley et al., 2000), where the mortality of embryos $<10 \%$ is avirulent, $10-29 \%$ is moderate virulence, and $>29 \%$ is high virulence. Reisolation of chorioallantoic was on EMB media, as confirmation of the cause of death was E. coli.

\section{Results and Discussion}

\section{Escherichia coli Isolates}

The E. coli serotypes O1K1, O2K1, O78K80, O157H7, and unknown serotype on EMB showed typically colony of metallic sheen (Figure 1a). The Gram staining showed a small rod Gram-negative (Figure 1b). This result is according to Swayne et al. (2013), Gordon and Jordan's (1982) where the growth of E. coli in EMB is metallic sheen, compared with the other Escherichia species. The cell morphology of bacterium is a small rod, Gram-negative, and does not have spores.

The results of biochemical tests, serotypes O1K1, O2K1, O78K80, O157H7, and unknown
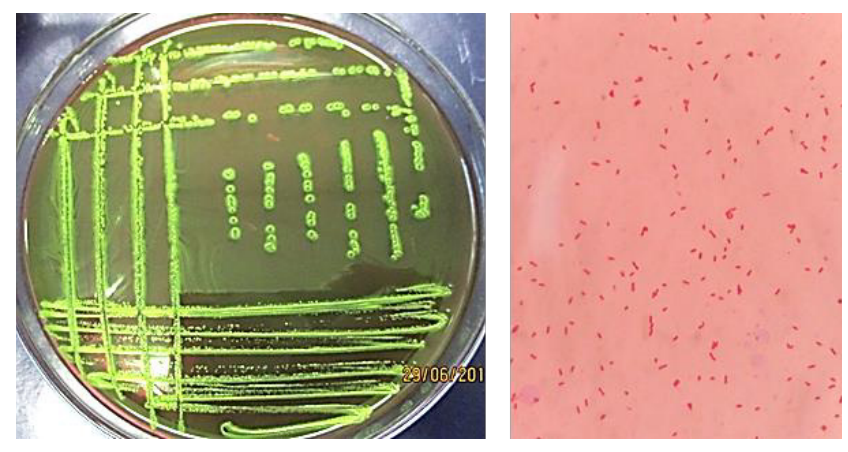

Figure 1. Characteristics of E. coli isolate. (A) The morphology of the E. coli on the EMB media was metallic green, (B) The E._coli cells were small rods, Gram-negative (red staining).

serotype on TSIA media could ferment all carbohydrates (glucose, lactose, sucrose) and have $\mathrm{CO}_{2}$ gas. Urea, $\mathrm{VP}$, and citrate were negative results. The bacterial positive on semisolid media, because $E$. coli have flagella. All isolates could fermented carbohydrates (sorbitol, glucose, lactose, sucrose, and mannitol), changed the color of the media to yellow, except unknown serotype which cannot ferment sucrose. All biochemical results according to Abott et al. (2003) and Nataro et al. (2011). The biochemical results are presented in Table 1

\section{Embryo Lethality Assay (ELA)}

The number of APEC serotypes O1K1, O2K1, O78K80, O157H7, and unknown

Table 1. The biochemist results of $E$. coli serotypes

\begin{tabular}{lccccc}
\hline \multicolumn{1}{c}{ Biochemist } & & & E. coli serotypes & & \\
& O1K1 & O2K1 & O78K80 & O157H7 & Unknown serotype \\
\hline TSIA & S: yellow & S: yellow & S: yellow & S: yellowB: yellow & S: yellow \\
& B: yellow & B: yellow & B: yellow & - & - \\
Urea & - & - & - & + & + \\
Semi solid & + & + & + & + & + \\
Indol & + & + & + & - & - \\
MR & + & + & - & + & + \\
VP & - & - & + & - & - \\
Catalase & + & + & + & + & + \\
Citrate & - & - & + & + \\
Sorbitol & + & + & + & + & + \\
Glucose & + & + & + & + & + \\
Lactose & + & + & + & + \\
Sucrose & + & + & + & + \\
Mannitol & + & + & + & + \\
\hline
\end{tabular}

S (slant), B (butt), + (positive result/ ferment carbohydrate), - (negative result/ couldn’t ferment carbohydrate) 
serotype as much as 100-500 CFU/ 0,1 ml were determined by the TPC method, then inoculated on chorioallantoic of 12-days old embryos, each 10 embryos/ serotype. After 6 days (18-days old), the result of $E$. coli serotypes $\mathrm{O} 1 \mathrm{~K} 1, \mathrm{O} 2 \mathrm{~K} 1$, and unknown serotype were the highest percentage of embryo mortality (100\%) than the other APEC serotypes. The O78K80 serotype has $90 \%$ of mortality, and the $0157 \mathrm{H} 7$ serotype has $70 \%$ (Table 2). The chickens in the control group did not have mortality. Virulence characteristics based on the percentage of embryo mortality according to Wooley et al. (2000), all the E. coli serotypes O1K1, O2K1, O78K80, O157H7, and unknown serotype were highly virulent. The high virulence of serotypes $\mathrm{O} 1 \mathrm{~K} 1, \mathrm{O} 2 \mathrm{~K} 1$, and $\mathrm{O} 78 \mathrm{~K} 80$ were in line with Wahyuwardani et al. (2014) with a case of broiler colibacillosis in Yogyakarta and Bogor, which were $\mathrm{O} 1 \mathrm{~K} 1, \mathrm{O} 2 \mathrm{~K} 1$, and $\mathrm{O} 78 \mathrm{~K} 80$ all of the 14 samples of $E$. coli isolates.

The 10 embryos used in each isolate to determine the $E$. coli virulence by previous research (Nabbut and Khatib, 1978). The percentage of mortality post-inoculated was significantly high, medium, or avirulent of APEC isolates (Wooley et al., 2000). The different mortality shows the ability of each isolate to be able to kill the embryo (Gibbs et al., 2003).

Although $\mathrm{O} 1, \mathrm{O} 2$, and $\mathrm{O} 78$ are the main E. coli serotypes that cause colibacillosis, there were many studied for other serotypes that cause colibacillosis, including O25, O125, O153 serotypes. This is proved that E. coli serotype is not an important factor for the pathogenesis of colibacillosis in chickens (Ozaki and Murase, 2009). The E. coli O157 serotype is one of the pathogenic serotypes in chickens experimentally. The E. coli $\mathrm{O} 157$ serotype is not only pathogens that infect poultry, but also in humans. Several studied have shown that poultry already has and persistently infected with E. coli O157 serotype (El-Sawah et al., 2018). The O157 serotype has also been reported isolated from pigeons, have lesions and histopathology that characterizes APEC infections (Dutta et al., 2013).

\section{Embryonic Lesions and Reisolation of Bacteria}

Lesions in dead embryos were cranial, skin, and extremity hemorrhages (Figure 2). These results according to Wooley et al. (2000), skin and cranial hemorrhages to encephalomalacia in embryos inoculated with virulent isolates. The presence of hemorrhage in the embryo is due to the massive growth and multiplication of bacteria in the tissues, the production and release of hemolytic factors, and other toxin factors (Nabbut and Khatib, 1978).

The iss gene is a virulence factor and strongly correlates with virulent E. coli isolates (Nolan et al., 1992). The iss gene of isolates can predict the percentage of embryo mortality. The iss genes, resistant complement, and CoIV production are strongly associated with virulence potential by chicken embryo lethality method. The chicken embryo can be used to distinguish APEC from commensal E. coli (Gibbs et al., 2003).

According to Wooley et al. (2000) control of colibacillosis is difficult because the lack of a diagnostic tool to determine the virulence of isolates. The results of this study are easy to do to determine virulence among isolates, because of the significant number of mortality and percentages (high ability to kill embryos). Most embryos would died 3-4 days post-inoculation, the most mortality usually 2 days post-inoculation (Gibbs et al., 2003; Nabbut and Khatib, 1978; Nolan et al., 1992; Powell and Finkelstein, 1966).

Table 2. The number and percentage of embryo mortality post-inoculated with APEC serotypes

\begin{tabular}{|c|c|c|c|c|c|c|c|c|}
\hline \multirow{2}{*}{ E. coli serotypes } & \multicolumn{7}{|c|}{ Embryo mortality post-inoculated/ day } & \multirow{2}{*}{$\begin{array}{c}\text { Percentage of } \\
\text { mortality }\end{array}$} \\
\hline & 1 & 2 & 3 & 4 & 5 & 6 & Total & \\
\hline O1K1 & 6 & 4 & 0 & 0 & 0 & 0 & $10 / 10$ & $100 \%$ \\
\hline $\mathrm{O} 2 \mathrm{~K} 1$ & 2 & 2 & 2 & 0 & 0 & 4 & $10 / 10$ & $100 \%$ \\
\hline O78K80 & 2 & 6 & 1 & 0 & 0 & 0 & $9 / 10$ & $90 \%$ \\
\hline O157H7 & 2 & 0 & 4 & 0 & 1 & 0 & $7 / 10$ & $70 \%$ \\
\hline Unknown serotype & 6 & 4 & 0 & 0 & 0 & 0 & $10 / 10$ & $100 \%$ \\
\hline
\end{tabular}



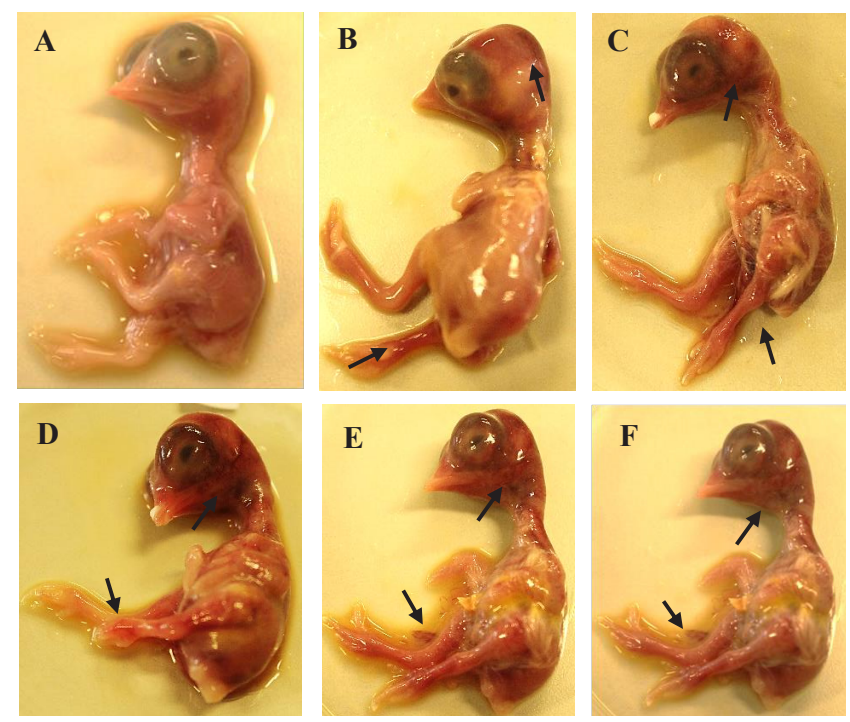

Figure 2. Lesions of embryo (cranial, skin, and extremity hemorrhage). (A) control, (B) inoculated with O1K1 serotype, (C) inoculated with O2K1 serotype, (D) inoculated with O78K80 serotype, (E) inoculated with $\mathrm{O} 157 \mathrm{H} 7$ serotype, (F) inoculated with unknown serotype.

\section{Conclusion}

The virulence characteristics of $E$. coli serotypes $\mathrm{O} 1 \mathrm{~K} 1, \mathrm{O} 2 \mathrm{~K} 1, \mathrm{O} 78 \mathrm{~K} 80, \mathrm{O} 157 \mathrm{H} 7$, and unknown serotype was highly virulence.

\section{References}

Abbot, S.L., O'Connor, J., Robin, T., Zimmer, B.L., Janda, J.M. (2003). Biochemical Properties of a Newly Described Escherichia Species, Escherichia albertii. Journal of Clinical Microbiology 41: 4852-4854.

Ahmed, H.A., Ali A.H.M., Baky M.H.A. (2015). Efficacy of a Live Escherichia coli Vaccine for Protection of Turkeys Against Homologous and Heterologous Field Strains Infection. Benha Veterinary Medical Journal 29(2): 11-16.

Andersson, C., Gripenland, J., Johansson, J. (2015). Using the Chicken Embryo to Assess Virulence of Listeria monocytogenes and to Model Other Microbial Infections. Nature Protocols 10(8): 1155-1164.

Chansiripornchai, V.R.N. (2009). The Efficacy of Escherichia coli AroA-Live Vaccine in Broilers Against Avian E. coli Serotype O78 Infection. Thai J. Vet. Med 39(4): 337-342.
Chansiripornchai, N., Mooljuntee, S., Boonkhum, P. (2011). Antimicrobial Sensitivity of Avian Pathogenic Escherichia coli (APEC) Isolated from Chickens During 2007-2010. Thai J Vet 41(4): 519-522.

Cortes, P., Blanc, V., Mora, A., Dahbi, G., Blanco, J.E., Blanco, M., Lopez, C., Andreu, A., Navarro, F., Alonso, M.P., Bou, G., Blanco, J., Llagostera, M. (2010). Isolation and Characterization of Potentially Pathogenic Antimicrobial-Resistant Escherichia coli Strains from Chicken and Pig Farms in Spain. Appl Environ Microbiol 76: 27992805.

Dho-Moulin, M., Fairbrother, J.M. (1999). Avian Pathogenic Escherichia coli (APEC). Veterinary Research 30: 299-316.

Dutta P., Borah, M.K., Sarmah, R., Gangil, R. (2013). Isolation, Histophatology, and Antibiogram of Escherichia coli from Pigeons (Columba livia). Vet World 6(2): 91-94.

El-Sawah, A., Dahshan, A.H.M., El-Nahass, S., El-Mawgoud, A.I.A. (2018). Pathogenicity of Escherichia coli $\mathrm{O} 157$ in Commercial Broiler Chickens. Beni-Suef University Journal of Basic and Applied Sciences $\operatorname{xxx}(\mathrm{xxx})$ : $\mathrm{xxx}-\mathrm{xxx}$.

Ghunaim, H., Abu-Madi, M.A., Kariyawasam, S. (2014). Advances in Vaccination Against Avian Pathogenic Escherichia coli Respiratory Disease: Potentials and Limitations. Veterinary Microbiology 172: 13-22.

Gregersen, R.H., Christensen, H., Ewers, C., Bisgaard, M. (2010). Impact of Escherichia coli Vaccine on Parent Stock Mortality, First Week Mortality of Broilers and Population Diversity of E. coli in Vaccinated Flocks. Avian Pathology 39(4): 287-295.

Gibbs, P.S., Maurer, J.J., Nolan, L.K., Wooley, R.E. (2003). Prediction of Chicken Embryo Lethality with the Avian Escherichia coli Traits Complement Resistance, Colicin V Production, and Presence of the Increased Serum Survival Gene Cluster (iss). Avian Disease 47: 370-379. 
Gordon, R.F., Jordan, F.T.W. (1982). Poultry Disease. 2nd Edition. The English Language Book Society and Bailliere Tindall. London. pp 31-37.

Gross, W.B. (1991). Colibasillosis. In: Diseases of poultry 9th Edition. Iowa State University Press, Ames, Iowa 138-144.

Kemmett, K., Humphrey, T., Rushton, S., Close, A., Wigley, P., Williams, N.J. (2013). A Longitudinal Study Simultaneously Exploring thr Carriage of APEC Virulence Associated Genes and The Molecular Epidemiology of Faecal and Systemic E. coli in Commercial Broiler Chicken. Plos One 8: e67749.

La Ragione, R.M.,Woodward, M.J., Kumar, M., Rodenberg, J., Fan, H., Wales, A.D., Karaca, K. (2013). Efficacy of a Live Attenuated Escherichia coli $\mathrm{O} 78$ and K80 Vaccine in Chickens and Turkeys. Avian Dis 57: 273279.

Nabbut, N., Khatib, I. (1978). Virulence of Escherichia coli Strains for Chicken Embryos. Avian Dis 22: 10-15.

Nolan, L.K., Wooley, R.E., Brown, J., Spears, K.R., Dickerson, H.W., Dekich, M. (1992). Comparison of a Complement Resistance Test, a Chicken Embryo Lethality Test, and the Chicken Lethality Test for Determining Virulence of Avian Escherichia coli. Avian Disease 36: 395-397.

Nataro, J.P., Bopp, C.A., Fields, P.I., Kaper, J.B., Strockbine, N.A. (2011). Escherichia, Shigella, and Salmonella. In: Manual of Clinical Microbiology, 10th ed Vol 1. Versalovic, J., Carroll, K.C., Funk, G., Jorgensen, J.H., Landry, M.L., Warnock, D.W. eds ASM Press, Washingon D.C. 603626.

Oh, J.Y., Kang, M.S., Yoon, H., Choi, H.W., An, B.K., Shin, E.G., Kim, Y.J., Kim, M.J., Kwon, J.H., Kwon, Y.K. (2012). The Embryo Lethality of Escherichia coli Isolates and Its Relationship to the Presence of Virulence-Associated Genes. Poultry Science 91: 370-375.
Ozaki, H., Murase, T. (2009). Multiple Routes of Entry for Escherichia coli Causing Colibacillosis in Commercial Layer Chickens. J. Vet. Med. Sci 71(12): 16851689.

Powell, C., Finkelstein, R. (1966). Virulence of Escherichia coli Strains for Chick Embryos. J. Bacterial 91: 1410-1417.

Roseliza, R., Khairani-Bejo, S., Zunita, Z., Ramlan, M., Khoo, E., Rosnah, Y. (2016). Antibiotic Resistence of Escherichia coli Isolated From Chicken in Malaysia. Malaysian Journal of Veterinary Research 7(1): 65-76.

Swayne, D.E., Glisson, J.R., Larry, R., McDougald, Nolan, L.K., David, L., Suarez, Nair, V. (2013). Disease of Poultry 13th Edition. Wiley Blackwell Publication.

Wahyuwardani, S., Noor, S.M., Poeloengan, M., Andriani, Aryanti, T. (2014). Kasus Kolibasilosis pada Peternakan Ayam Pedaging di Yogyakarta dan Bogor. Seminar Nasional Teknologi Peternakan Dan Veteriner.

Wibowo, M.H., Amanu, S. (2009). Efektivitas Pengobatan Preparat Kombinasi Amoksisilin dan Kolistin Sulfat pada Kasus Infeksi Buatan Escherichia coli Patogen pada Ayam Broiler. J. Sain Vet 27(1): 1-9.

Wooley, R.E., Gibbs, P.S., Brown, T.P., Maurer, J.J. (2000). Chicken Embryo Lethality Assay for Determining the Virulence of Avian Escherichia coli Isolates. Avian Disease 44: 318-324. 